\title{
Kesesuaian antara Metode Microscopic Observation Drug Susceptibility Assay dan Ogawa pada Biakan Mycobacterium tuberculosis
}

\author{
Ni Sayu Dewi B, ${ }^{1}$ Ida Parwati, ${ }^{1}$ Bachti Alisjahbana, ${ }^{2}$ Dewi Kartika Turbawaty ${ }^{1}$ \\ ${ }^{1}$ Balai Besar Laboratorium Kesehatan Jakarta, ${ }^{2}$ Departemen Ilmu Penyakit Dalam \\ Fakultas Kedokteran Universitas Padjadjaran-Rumah Sakit Dr. Hasan Sadikin, Bandung
}

\begin{abstract}
Abstrak
Tuberkulosis (TB) merupakan masalah kesehatan masyarakat di berbagai negara di dunia. Diagnosis pasti TB ditegakkan berdasarkan penemuan kuman $M$. tuberculosis pada pemeriksaan mikroskopik atau biakan sputum. Biakan merupakan baku emas, namun metode yang digunakan saat ini membutuhkan waktu minimal 8 minggu. Microscopic observation drug susceptibility assay (MODS) merupakan metode biakan untuk M. tuberculosis menggunakan media cair yang dapat sekaligus menguji kepekaan obat TB secara mikroskopik. Tujuan penelitian ini adalah untuk mengetahui kesesuaian metode MODS dengan metode Ogawa (media padat) untuk biakan M. tuberculosis pada penderita TB paru. Penelitian cross sectional telah dilakukan di Departemen Patologi Klinik RSUP Dr. Hasan Sadikin Bandung dan pemeriksaan spesimen dilakukan di Balai Pengembangan Laboratorium Kesehatan (BPLK) Provinsi Jawa Barat periode April-Agustus 2010. Subjek penelitian sebanyak 133 penderita yang didiagnosis tersangka TB paru. Setiap spesimen ditanam pada dua media, media cair MODS dan media padat Ogawa. Analisis statistik kesesuaian metode MODS dengan Ogawa menggunakan uji koefisien Kappa. Terdapat 172 spesimen dari 133 subjek. Kesesuaian antara hasil biakan M. tuberculosis metode MODS dan Ogawa didapatkan nilai Kappa 0,91 yang berarti terdapat kesesuaian yang tinggi antara metode MODS dan Ogawa. Perbandingan waktu pertumbuhan $M$. tuberculosis secara bermakna lebih cepat $(\mathrm{p}=0,000)$ pada metode MODS, yaitu 10,1 hari (rentang 4-21 hari), dibandingkan dengan metode Ogawa, yaitu 24,8 hari (rentang 14-35 hari). Simpulan, metode MODS dan Ogawa mempunyai angka keberhasilan diagnostik yang relatif sama, keunggulan metode MODS adalah pertumbuhan M. tuberculosis lebih cepat dibandingkan dengan metode Ogawa.
\end{abstract}

[MKB. 2011;43(2):83-8].

Kata kunci: Microscopic observation drug susceptibility assay (MODS), M. tuberculosis, Ogawa, sputum

\section{Conformity Method Between Microscopic Observation Drug Susceptibility Assay and Ogawa Mycobacterium Culture}

\begin{abstract}
Tuberculosis (TB) is a problem of public health that causing high morbidity and mortality rates in various countries in the world. The diagnosis of pulmonary tuberculosis in adults can be established based on the discovery of M. tuberculosis on smear or culture of sputum. Culture is the gold standard but the availlable method is time consuming, it is need minimal eight weeks. Microscopic observation drug susceptibility assay (MODS) is one of methods for $M$. tuberculosis culture using liquid medium that can be a simultaneously test for $M$. tuberculosis drug sensitivity. The purpose of this study was to determine the conformity of the MODS method compared with Ogawa method for cultivation of $M$. tuberculosis in pulmonary TB patients. The cross sectional research has been conducted at Clinical Pathology Department of Dr. Hasan Sadikin Hospital, Bandung and examination of the specimen done at Health Laboratory Development Unit (BPLK), West Java Province between April to August 2010. The subjects were patients who diagnosed as pulmonary TB suspect. Each collected specimen was cultured in liquid media MODS and solid media Ogawa. To analyze the conformity of MODS and Ogawa method, Kappa coefficient of agreement was used. There were 172 specimens collected from 133 subjects. The conformity between culture results of $M$. tuberculosis in MODS method and in Ogawa's method using Kappa coefficient, was high (Kappa index 0.91). The difference of growth time of $M$. tuberculosis significant ( $\mathrm{p}=0.000)$, in MODS was 10.1 days (range 4-21 days) and in Ogawa method was 24.8 days (range 14-35 days). Conclusion, MODS and Ogawa's method have the relatively similar diagnostic success rate, the advantage of MODS method is, the growth of M. tuberculosis is faster than in Ogawa method. [MKB. 2011;43(2):83-8].
\end{abstract}

Key words: Microscopic observation drug susceptibility assay (MODS), M. tuberculosis, Ogawa, sputum

Korespondensi: Ni Sayu Dewi Budhiyani, dr, Balai Besar Laboratorium, jalan Percetakan Negara 23B Jakarta Pusat, mobile 08122005989, e-mail: nisayudewi@yahoo.com 


\section{Pendahuluan}

Tuberkulosis (TB) adalah penyakit infeksi menular dan kronik yang disebabkan oleh kuman Mycobacterium tuberculosis complex. ${ }^{1-3}$ Tuberkulosis merupakan masalah kesehatan masyarakat yang menimbulkan angka kesakitan dan kematian yang tinggi di berbagai negara di dunia. Penyakit ini menyerang sebagian besar kelompok usia produktif, ekonomi lemah, dan berpendidikan rendah. World Health Organization (WHO) pada tahun 2004 memperkirakan kuman Mycobacterium tuberculosis (M. tuberculosis) telah menginfeksi sepertiga penduduk dunia dan setiap tahun lebih dari 8,9 juta kasus baru TB (140/100.000 penduduk) dengan kira-kira dua juta orang meninggal karena penyakit ini. ${ }^{4-}$ ${ }^{7}$ Indonesia menempati urutan ketiga terbanyak dalam kasus TB di dunia setelah India dan Cina. Pada tahun 2004, WHO melaporkan di Indonesia diperkirakan setiap tahun terdapat 539.000 kasus baru TB dengan angka kematian kira-kira 101.000 penderita per tahun. ${ }^{8}$

Diagnosis TB paru pada orang dewasa dapat ditegakkan berdasarkan penemuan kuman $M$. tuberculosis pada pemeriksaan biakan atau ditemukan bakteri tahan asam pada pemeriksaan sputum. Pemeriksaan biakan kuman merupakan pemeriksaan baku emas (gold standard) untuk menegakkan diagnosis TB. Media pembiakan terdiri atas dua bagian besar, yaitu media padat dan media cair; media padat ada yang berbasis telur dan ada yang berbasis agar. ${ }^{9}$ Media padat berbasis telur, seperti Lowenstein Jensen (LJ) dan metode Ogawa merupakan metode biakan yang banyak digunakan saat ini sebagai baku emas. Metode Ogawa lebih banyak digunakan di negara berkembang karena lebih ekonomis dan bahan yang dibutuhkan lebih sedikit, sehingga lebih murah dan lebih mudah dibuat dibandingkan dengan metode LJ. ${ }^{10-12}$ Kekurangan metode Ogawa adalah waktu yang diperlukan cukup lama untuk mendapatkan hasil yang positif. 2,8 Penelitian mengenai pemeriksaan biakan untuk menegakkan diagnosis TB terus dikembangkan, hingga pada tahun 2000 telah ditemukan metode pemeriksaan biakan yang disebut microscopic observation drug susceptibility assay (MODS). ${ }^{13,14}$ Metode MODS merupakan metode biakan untuk kuman M. tuberculosis dengan media Middlebrook 7H9 yang sekaligus dapat mendeteksi kepekaan obat TB secara mikroskopik. Uji kepekaan tersebut difasilitasi dengan Middlebrook 7H9 ditambah obat anti-TB. Metode MODS mempunyai sensitivitas yang lebih tinggi dibandingkan dengan metode biakan yang lain dan dapat mendeteksi lebih cepat pertumbuhan $M$. tuberculosis dengan biaya yang relatif lebih murah serta cara yang mudah. ${ }^{13-15}$

Tujuan penelitian ini adalah untuk menentukan kesesuaian antara metode MODS dan Ogawa pada biakan M. tuberculosis dalam mendiagnosis TB paru dewasa.

\section{Metode}

Subjek pada penelitian adalah penderita suspek TB paru yang dirawat dan berobat jalan di Subbagian Pulmonologi Departemen/SMF Ilmu Penyakit Dalam FK Unpad/RS Dr. Hasan Sadikin Bandung. Kriteria inklusi adalah penderita berusia $>14$ tahun yang didiagnosis oleh klinisi sebagai penderita suspek TB paru berdasarkan gejala klinis (batuk $\geq 3$ minggu/batuk berdarah, sesak napas, nyeri dada, penurunan berat badan, anoreksia, sakit kepala, badan pegal-pegal, demam subfebris yang disertai keringat malam), gambaran radiologis (lesi aktif, kalsifikasi, infiltrat, kavitas), dan mikroskopis BTA $(+)$ maupun BTA(-). Selain itu juga penderita TB yang pernah menjalani pengobatan TB, tetapi BTA $(+)$ dan penderita TB yang pernah menjalani pengobatan TB tetapi drop out (DO) dan BTA $(+)$ serta menandatangani persetujuan turut serta dalam penelitian (informed consent). Kriteria eksklusi adalah penderita yang sedang menjalani pengobatan TB dan penderita dengan penurunan kesadaran. Bahan pemeriksaan adalah sputum subjek penelitian sebanyak 3 kali (SPS=sewaktu, pagi, sewaktu) untuk pemeriksaan mikrobiologi.

Penelitian dilakukan di Laboratorium Patologi Klinik Rumah Sakit Umum Pusat Dr. Hasan Sadikin Bandung dan pemeriksaan spesimen dilakukan di Balai Pengembangan Laboratorium Kesehatan (BPLK) Provinsi Jawa Barat periode April-Agustus 2010 dengan bentuk penelitian observasional dengan rancangan penelitian cross sectional dan comparative. Data dikumpulkan dan diolah dengan program SPSS for Windows versi 18.0 dan analisis data dilakukan dengan menghitung kesesuaian koefisien Kappa (Карpa coefficient of agreement $=k$ ) di antara kedua metode pemeriksaan yang dihitung dengan tabel proporsi $2 \times 2$. Terdapat tiga kriteria nilai batasan Kappa, yaitu jika Kappa $>0,74$ disebut kesesuaian tinggi, jika Kappa 0,40-0,74 disebut kesesuaian sedang, dan jika $<0,40$ disebut kesesuaian kurang.

\section{Hasil}

Selama kurun waktu tersebut diperoleh 372 spesimen yang berasal dari 133 subjek penelitian yang memenuhi kriteria inklusi. Pada semua spesimen dilakukan pemeriksaan BTA I, II dan III, serta dilakukan kultur Ogawa dan MODS pada pencampuran spesimen BTA I, II, dan III.

Karakteristik subjek penelitian menurut jenis 
Tabel 1 Karakteristik Subjek Penelitian Menurut Jenis Kelamin dan Usia

\begin{tabular}{cc}
\hline Variabel & $\mathbf{n}(\mathbf{\%})$ \\
\hline Jenis kelamin & \\
Laki-laki & $86(64,7)$ \\
Usia (tahun) & $47(35,3)$ \\
Rerata (SB) & \\
Median & $36,9(12,8)$ \\
Minimum-Maksimum & 33 \\
$15-24$ & $15-76$ \\
$25-34$ & $13(9,7)$ \\
$35-44$ & $65(48,9)$ \\
$45-54$ & $26(19,5)$ \\
$55-64$ & $16(12,0)$ \\
$65-74$ & $3(2,3)$ \\
$>74$ & $9(6,8)$ \\
Total & $1(0,8)$ \\
& $133(100)$ \\
\hline
\end{tabular}

kelamin dan usia pada penderita TB paru di Rumah Sakit Dr. Hasan Sadikin Bandung dapat dijelaskan pada Tabel 1.

Berdasarkan Tabel 1 terlihat bahwa rasio lakilaki dan perempuan adalah 64,7:35,3. Usia ratarata subjek penelitian adalah 36,9 tahun (median 33 tahun, rentang 15-76 tahun). Tabel di atas juga menunjukkan bahwa subjek penelitian paling banyak pada usia $25-34$ tahun (48,9\%).

Pemeriksaan mikroskopis dengan pewarnaan Ziehl-Neelsen (ZN) dilakukan pada spesimen BTA I, II, dan III. Dari hasil pemeriksaan BTA I, II, dan III dipilih hasil positif yang paling tinggi di antara ketiga hasil pemeriksaan tersebut. Hasil pemeriksaan mikroskopis dengan pewarnaan $\mathrm{ZN}$ dapat dilihat pada Tabel 2.

Pada Tabel 2 terlihat bahwa hasil pemeriksaan mikroskopis dengan pewarnaan $\mathrm{ZN}$ didapatkan angka positif sebesar $17,3 \%$. Pembacaan sediaan apus BTA dengan pewarnaan $\mathrm{ZN}$ pada penelitian ini berdasarkan skala modifikasi International Union Against Tuberculosis and Lung Disease (IUATLD).

Hasil pemeriksaan biakan dengan metode Ogawa dapat dilihat pada Tabel 3. Pemeriksaan biakan dengan metode Ogawa mendapatkan angka biakan sebesar $23,3 \%$ dan terdapat hasil kontaminasi sebanyak $0,8 \%$.

Hasil pemeriksaan biakan dengan metode MODS dapat dilihat pada Tabel 4.

Terlihat bahwa hasil biakan dengan metode MODS hasil positif, indeterminate, dan kontaminasi berturut-turut 24,8\%; 3,8\%; dan 4,5\%. Hasil indeterminate disimpulkan apabila terdapat hanya salah satu hasil positif pada sumur baris A atau B (pada plat MODS) atau bila terdapat hanya 1 colony forming units (CFU) pada salah satu sumur.

Kesesuaian hasil biakan M. tuberculosis pada metode MODS dengan metode Ogawa dapat dilihat pada Tabel 5.

Pada Tabel 5 dapat dilihat bahwa kesesuaian hasil biakan $M$. tuberculosis metode MODS dengan metode Ogawa didapatkan indeks Kappa sebesar 0,91 $(\mathrm{p}<0,001)$. Analisis statistik pada tabel ini hanya pada hasil positif dan negatif, sedangkan hasil indeterminate dan kontaminasi tidak dimasukkan dalam analisis.

\section{Pembahasan}

Berdasarkan Tabel 1 terlihat bahwa sebagian besar subjek penelitian adalah laki-laki. Berdasarkan

Tabel 2 Hasil Pemeriksaan Mikroskopis Ziehl-Neelsen

\begin{tabular}{ccc}
\hline Hasil Pemeriksaan Ziehl-Neelsen & $\mathbf{n}$ & $\mathbf{\%}$ \\
\hline Negatif & 110 & 82,7 \\
Positif & 23 & 17,3 \\
Scanty & 1 & 0,8 \\
Positif 1 & 8 & 6,0 \\
Positif 2 & 6 & 4,5 \\
Positif 3 & 8 & 6,0 \\
\hline Total & $\mathbf{1 3 3}$ & $\mathbf{1 0 0 , 0}$ \\
\hline
\end{tabular}


Tabel 3 Hasil Pemeriksaan Biakan dengan Metode Ogawa

\begin{tabular}{ccc}
\hline $\begin{array}{c}\text { Hasil Pemeriksaan Biakan } \\
\text { Metode Ogawa }\end{array}$ & $\mathbf{n}$ & $\mathbf{\%}$ \\
\hline Negatif & 101 & 75,9 \\
Positif & 31 & 23,3 \\
$<50$ koloni & 10 & 7,5 \\
Positif 1 & 10 & 7,5 \\
Positif 2 & 8 & 6,0 \\
Positif 3 & 3 & 2,3 \\
Kontaminasi & 1 & 0,8 \\
\hline Total & $\mathbf{1 3 3}$ & $\mathbf{1 0 0 , 0}$ \\
\hline
\end{tabular}

kepustakaan penyakit TB lebih banyak terjadi pada laki-laki, hal ini disebabkan mobilitas lakilaki lebih tinggi, sehingga lebih mudah terpapar M. tuberculosis melalui kontak dengan penderita TB lainnya. ${ }^{2}$ Di Amerika Serikat data tentang epidemiologi TB dinyatakan bahwa TB lebih banyak terjadi pada laki-laki. Pada tahun 1985 prevalensi TB pada laki-laki adalah $65 \%$ dari semua penderita TB, sedangkan pada tahun 1997 prevalensi laki-laki $62 \%$ dari semua penderita TB. ${ }^{2,15}$

Tabel 1 menunjukkan pula bahwa usia ratarata subjek penelitian adalah 36,9 tahun dengan simpangan baku 12,8 tahun, sedangkan median usia 33 tahun dengan usia termuda 15 tahun dan usia tertua 76 tahun. Sebagian besar subjek penelitian berada pada kelompok usia 25-34 tahun $(48,9 \%)$ dan paling sedikit pada kelompok usia $>74$ tahun $(0,8 \%)$. Hal ini sesuai dengan data dari berbagai kepustakaan bahwa penyakit TB dapat terjadi pada semua kelompok usia, tetapi yang tertinggi terjadi pada usia produktif, yaitu usia 25-50 tahun. . $^{2,4,6,7}$
Berdasarkan Tabel 2 hasil pemeriksaan mikroskopis dengan pewarnaan ZN mendapatkan angka positif sebesar 17,3\%. Pada Tabel 3 hasil biakan positif dengan metode Ogawa didapatkan 23,3\%, sedangkan pada Tabel 4 hasil biakan positif dengan metode MODS sebesar 24,8\%. Keberhasilan diagnostik dengan metode MODS secara bermakna lebih tinggi dibandingkan dengan pemeriksaan mikroskopis pewarnaan $\mathrm{ZN}$ $(p<0,001)$. Beberapa kepustakaan menyebutkan bahwa sensitivitas pemeriksaan mikroskopis dengan pewarnaan $\mathrm{ZN}$ pada spesimen sputum adalah $50-70 \%{ }^{2,16} \mathrm{Hal}$ ini disebabkan karena hasil positif pada pemeriksaan ini diperoleh bila spesimen mengandung paling sedikit 5.000$10.000 \mathrm{BTA} / \mathrm{mL}$ spesimen., ${ }^{2,17}$ Metode MODS dibandingkan dengan metode Ogawa mempunyai angka biakan yang secara bermakna lebih tinggi $(\mathrm{p}<0,001)$, hal ini merupakan nilai tambah pada metode MODS karena selain pengerjaan dan alat-alat yang sederhana metode MODS mampu mendeteksi TB lebih tinggi dibandingkan dengan Ogawa. Hal ini juga dapat dilihat pada Tabel 5,

Tabel 4 Hasil Pemeriksaan Biakan dengan Metode MODS

\begin{tabular}{ccc}
\hline $\begin{array}{c}\text { Hasil Pemeriksaan Biakan } \\
\text { Metode MODS }\end{array}$ & $\mathbf{n}$ & $\mathbf{\%}$ \\
\hline Negatif & 89 & 66,9 \\
Positif & 33 & 24,8 \\
Indeterminate & 5 & 3,8 \\
Kontaminasi & 6 & 4,5 \\
\hline Total & $\mathbf{1 3 3}$ & $\mathbf{1 0 0 , 0}$ \\
\hline
\end{tabular}

Tabel 5 Kesesuaian Hasil Biakan M. tuberculosis Metode MODS dengan Metode Ogawa

\begin{tabular}{lccccc}
\hline \multirow{2}{*}{ Metode MODS } & \multicolumn{2}{c}{ Metode Ogawa } & \multirow{2}{*}{ Jumlah } & Indeks Kappa & \multirow{2}{*}{ Nilai p } \\
\cline { 2 - 3 } & Positif & Negatif & & 0,91 & $<0,001$ \\
\hline Positif & 29 & 4 & 33 & & \\
Negatif & 0 & 89 & 89 & & \\
\hline Total & $\mathbf{2 9}$ & $\mathbf{9 3}$ & $\mathbf{1 2 2}$ & & \\
\hline
\end{tabular}


yaitu kesesuaian hasil biakan $M$. tuberculosis metode MODS dengan metode Ogawa. Selama ini Ogawa dianggap sebagai biakan standar untuk M. tuberculosis. Dengan hasil false positif (4/122), maka bila metode MODS digunakan tidak akan ada yang luput sehingga metode MODS dapat digunakan untuk menggantikan Ogawa.

Kesesuaian hasil dari biakan M. tuberculosis metode MODS dengan Ogawa dianalisis dengan menghitung kesesuaian koefisien Kappa (Kappa coefficient of agreement $=k$ ), dengan tabel proporsi $2 \times 2$. Berdasarkan Tabel 5 terlihat bahwa hasil biakan positif pada metode MODS dan metode Ogawa sebanyak 29 (87,9\%), sedangkan hasil biakan negatif pada metode MODS dan metode Ogawa sebanyak 89 (100\%). Hasil penelitian ini menunjukkan bahwa persentase hasil pertumbuhan M. tuberculosis pada metode Ogawa sesuai dengan metode MODS. Hasil uji kai-kuadrat menunjukkan bahwa kesesuaian hasil biakan metode MODS dan metode Ogawa adalah bermakna dengan nilai $\mathrm{p}<0,001$ dan indeks Kappa sebesar 0,91 yang menunjukkan kesesuaian tingkat tinggi. Hal ini berarti bahwa metode MODS dapat dijadikan metode alternatif untuk menggantikan metode Ogawa mengingat tidak ada perbedaan nilai positivitas antara metode MODS dan Ogawa.

Waktu tumbuh pada biakan metode MODS dihitung mulai saat penanaman sampai terlihat pertumbuhan cord serpentine, $\geq 2$ colony forming unit (CFU) secara mikroskopis, sedangkan pada metode Ogawa dihitung sejak penanaman sampai terlihat pertumbuhan $M$. tuberculosis sebagai koloni. Sebelum dilakukan analisis tentang perbandingan waktu tumbuh $M$. tuberculosis pada metode MODS dengan metode Ogawa, perlu dilakukan uji normalitas untuk variabel waktu tumbuh dengan uji Kolmogorov-Smirnov. Hasil uji normalitas menunjukkan nilai $\mathrm{p}>0,05$; artinya data waktu tumbuh $M$. tuberculosis dengan metode MODS dan Ogawa berdistribusi normal, sehingga uji statistik yang digunakan adalah independent $t$ test. Deteksi pertumbuhan M. tuberculosis secara bermakna lebih cepat $(\mathrm{p} \leq 0,05)$ pada metode MODS dengan waktu pertumbuhan rata-rata 10,1 hari (rentang 4-21 hari), dibandingkan dengan metode Ogawa, yaitu 24,8 hari (rentang 14-35 hari). Perbedaan waktu tumbuh pada penelitian ini tidak jauh berbeda dengan penelitian sebelumnya. Caviedes dkk. ${ }^{9}$ mendapatkan waktu tumbuh rata-rata pada metode MODS 9 hari (rentang 4-31 hari) dan pada LJ 24 hari (rentang 6-59 hari). Moore dkk. ${ }^{13}$ mendapatkan waktu tumbuh ratarata pada metode MODS 7 hari dan metode LJ 26 hari. Demikian juga dengan Arias dkk. ${ }^{18}$ mendapatkan waktu tumbuh rata-rata pada metode MODS 7 hari, sedangkan pada metode LJ 21 hari. Perbedaan waktu tumbuh rata-rata $M$. tuberculosis pada metode MODS dan Ogawa $( \pm 14$ hari) sangat berarti dalam mendiagnosis $\overline{\mathrm{TB}}$, sehingga penatalaksanaan klinis menjadi lebih cepat dan tepat.

Bakteri atau jamur kontaminan dapat tumbuh bersama-sama $M$. tuberculosis maupun tumbuh sendiri. Pada penelitian ini kontaminasi lebih banyak terjadi pada metode MODS, yaitu 4,5\% dibandingkan dengan metode Ogawa, yaitu $0,8 \%$. Kontaminasi pada metode MODS lebih besar dibandingkan dengan metode Ogawa, karena metode MODS merupakan media yang sangat kaya nutrisi, sehingga memungkinkan untuk pertumbuhan bakteri lain dan karakteristik spesimen sputum yang banyak mengandung flora normal menyebabkan spesimen masih mengandung mikroorganisme lain, meskipun sudah dilakukan proses digesti-dekontaminasi. Beberapa hal yang dapat berpengaruh pada terjadinya kontaminasi, terutama pada metode MODS adalah: 1) spesimen memang sudah mengandung mikroorganisme dalam jumlah banyak, sehingga proses dekontaminasi tidak dapat membunuh habis semua mikroorganisme kontaminan ini dan 2) proses pengerjaan metode MODS yang memungkinkan banyak terjadi kontaminasi karena bentuk plat dengan sumur yang banyak ( 1 plat terdiri atas 24 sumur untuk 5 subjek penelitian), sehingga pada proses inokulasi terjadi buka tutup plat beberapa kali yang memungkinkan kontaminasi lebih besar.

Pada penelitian ini didapatkan kontaminasi dengan metode Ogawa sebesar $0,8 \%$; lebih kecil dibandingkan dengan hasil penelitian yang lain. Lubasi dkk. ${ }^{12}$ mendapatkan kontaminasi biakan M. tuberculosis dengan metode Ogawa sebesar $5,1 \%$, sedangkan Abe dkk. ${ }^{19}$ mendapatkan kontaminasi dengan metode Ogawa sebesar 5,3\%. Kontaminasi dengan metode MODS lebih besar dibandingkan dengan penelitian sebelumnya. Caviedes dkk. ${ }^{9}$ mendapatkan angka kontaminasi metode MODS sebesar 2\%, sedangkan Shiferaw dkk. ${ }^{20}$ mendapatkan kontaminasi lebih kecil, yaitu $0,4 \%$. Berbeda dengan yang lain, Moore dkk. ${ }^{13}$ mendapatkan kontaminasi metode MODS lebih besar, yaitu $8,1 \%$.

Pada penelitian ini deteksi hasil indeterminate dan kontaminasi dengan metode MODS harus dapat diantisipasi, mengingat angka yang cukup besar, yaitu 8,3\%. Hasil indeterminate dan kontaminasi sebaiknya diulang dengan menggunakan bahan baru dan sedapat-dapatnya dalam waktu secepatnya.

Simpulan, metode MODS dan Ogawa mempunyai angka keberhasilan diagnostik yang 
relatif sama (kesesuaian tinggi dengan indeks Kappa 0,91) dan pertumbuhan M. tuberculosis pada metode MODS lebih cepat dibandingkan dengan metode Ogawa.

\section{Daftar Pustaka}

1. Daniel TM. Tuberculosis. Dalam: Braunwald E, Isserbacher KJ, Petersdorf RG, Wilson JD, Martin JB, Fauci AS, penyunting. Harrison's principles of internal medicine. Edisi ke-11. Philadelphia: Mc Graw Hill Co; 1987. hlm. 625-32.

2. Iseman MD. A clinician's guide to tuberculosis. Philadelphia, USA: Lippincott Williams \& Wilkins; 2000.

3. Kanyok TP. Tuberculosis (diunduh 14 September 2008). Tersedia dari: http:// www.iuc.edu/pharmacy/courses/pmpr 342/ kanyok/tb97.htm.

4. Enarson DA, Chiang CY, Murray JF. Global epidemiology of TB. Dalam: Rom WN, Garay SM, penyunting. Tuberculosis. Edisi ke-2. Philadelphia: Lippincot Williams \& Wilkins; 2004. hlm. 3-45.

5. Global Tuberculosis Programme. Treatment of tuberculosis: guidelines for national programmes. Edisi ke-3. Geneva, Switzerland: WHO; 2003.

6. WHO. Global TB Control 2006 (diunduh 10 September 2008). Tersedia dari: http://www. who.int/tb/publication/globalreport/en

7. Chauhan LS, Roy D. Epidemiology of tuberculosis (diunduh 10 September 2008). Tersedia dari: http://www.tbcindia.org/pdfs/ Tuberculosis.html.

8. Departemen Kesehatan Republik Indonesia. Pedoman Nasional Penanggulangan TB. Edisi ke-2. Jakarta: Dirjen P2M \& PLP. Depkes RI; 2006.

9. Caviedes L, Lee TS, Gilman RH, Sheen P, Spellman E, Lee EH. Rapid efficient detection and drug susceptibility testing of Mycobacterium tuberculosis in sputum by microscopic observation of broth cultures. J Clin Microbiol. 2000;38(3):1203-8.

10. Kanai K. Introduction to tuberculosis and mycobacteria. Tokyo Japan: Seamic Pub; 1991.
11. Weyer K, Valenzuela P, Lueelmo F, Laszlo A, Frieden T, Kim SJ, dkk. Laboratory services in tuberculosis control. Part III: culture. Biella: WHO; 1998.

12. Lubasi D, Habeenzu C, Mitarai S. Evaluation of an Ogawa Mycobacterium culture method modified for higher sensitivity employing concentrated samples. Tropical Med Health. 2004;32(1):1-4.

13. Moore DA, Evans CA, Gilman RH, Caviedes L, Coronel J, Vivar A, dkk. Microscopicobservation drug-susceptibility assay for the diagnosis of TB. N Engl J Med. 2006;355:153950.

14. Caviedes L, Moore DAJ. Introducing MODS: a low-cost, low-tech tool for high performance detection of tuberculosis and multidrug resistant tuberculosis. Indian $\mathrm{J}$ Med Microbiol. 2007;25(2):87-8.

15. Centers for Disease Control and Prevention. Division of tuberculosis. Elimination tuberculosis morbidity-United States, 1997. MMWR. 1998;47:253-7.

16. Tuberculosis Coalition for Technical Assistance. International Standards for Tuberculosis Care. Tuberculosis coalition for technical assistance. Edisi ke-2. Netherland: The Hague; 2009.

17. Mirovic P, Lepzanovic Z. Evalution of MB/ BacT system for recovery of from clinical specimens in comparison to LowensteinJensen media. Clin Microb Infect. 2002;8:709-14.

18. Arias M, Mello FC, Pavon A, Marsico AG, Galves CA, Rosales S, dkk. Clinical evaluation of the microscopic-observation drug-susceptibility assay for detection of tuberculosis. Clin Infect Dis. 2007;44:67480.

19. Abe C, Hosojima S, Fukasawa Y, Kazumi Y, Takahashi M, Hirano K, dkk. Comparison of MB-check, bactec, and egg-based media for recovery of Mycobacteria. J Clin Microbiol. 1992;30(4):878-81.

20. Shiferaw G, Woldeamanuel Y, Gebeyehu M, Girmachew F, Demessie D, Lemma E. Evaluation of microscopic observation drug susceptibility assay for detection of multidrugresistant Mycobacterium tuberculosis. J Clin Microbiol. 2007 April;45:1093-7. 